\title{
MASS REVOLUTION AND END OF THE CULTURAL INSTITUTION IN NEPAL
}

\author{
Apar Kumar Lamsal \\ Tribhuvan University \\ aparkumar1@gmail.com
}

\begin{abstract}
From $6^{\text {th }}$ April to $24^{\text {th }}$ April of 2006, parliamentary political parties along with the ten years long strafing underground Nepal Communist Party (Maoists) stage a mass revolution against the Royal takeover of 2002 AD for the establishment of republican state. This mass movement gained much impetus then trailed by various organizations, trade unions, students, professional employees and the general mass throughout the kingdom of Nepal. Ultimately, the age-long monarchical institution was finished from the political and cultural scenario of Nepal. This article outlines the main events and outcomes of this revolution and analyzes it. This article is based on secondary sources along with event observation.
\end{abstract}

Key words: mass revolution, monarchy, political parties

\section{Background of the Mass Revolution}

After the restablishment of parliamentary democracy system in 1990AD, the people of Nepal had a hope and trust in peoples participation and more freedom. The also had hoped that the people's representatives government would give freedom, relief, peace, development and security but due to political instability, corruption, lack of understanding among major political parties, failure to maintain law and order and security, the political parties failed to secure the trust and support of the people. At this crucial moment, the Royal massacre of Birendra's family and enthronement of a king 
Gyanendra abruptly dismissed the people's elected 'House of Representative' on May 22, 2002 and the Government on Oct 4, 2002 and took the country's rule by appointing the council of minister according to his own will. In the preliminary stage, the political parties made attempt to convince the king to form the new government from their party members but when they failed, they were forced to stage a peaceful demonstration. After sometime the king reconstituted the new cabinet on June 2, 2004 including to the two demonstrating parties, Nepal Communist Party (UML) and Nepali Congress (Democratic), but the remaining four alliance including Nepali Congress, Joint People Front Nepal, Nepal Workers-Peasant Party, and Nepal Sadbhawana Party (Aanandidebi) gave continuity to the demonstration. Similarly on Feb, 1, 2005, the king dismissed the cabinet and formed the new Government under his own chairmanship. The ousted political parties UML and NC (Democratic) joined the revolutionary wings again.

The period from Oct. 4, 2002 till April 5, 2006 was mostly followed by protest like relay, hunger strike, mass gatherings, peaceful demonstration, gherau, black outs etc organized by the political parties. However, it did not get wholehearted sympathy from various organizations, government employees and the general mass due to the difference in attitude of the political parties in their outlooks lacked momentum. Therefore, the seven agitating parties NC, NC (Democratic), NCP (UML), NWPP, JPFN, NSP (Aanandedevi) and United Leftist Front on 22 Nov.2005 signed a 12-point understanding with the Maoist Party to launch a unified movement. Under the foundation of this agreement, the seven party alliances called the strike from April 6, 2006 for four days where the Maoist had participated in the mass movement undeclared. 


\section{Nineteen Days of Mass Revolution}

The Seven party alliances in a press release on March 19, 2006 called for the 4 days strike, 6th April till 9th April, to the people. The press release stated: "They are committed for the restoration of the House of Representatives by the power of people's movement. From the decision of that movement establishing all party Government, dialogue with Maoists and conduct constituent assembly election on the basis of reconciliation and then establishing full democracy from which the conflict in the country can be resolved and the sovereignty and the state power can be bestowed upon people"(Aryal \& Poudel, 2006: 11). As such, the Maoists declared unilateral ceasefire in Kathmandu Valley after the seven agitating party alliance issued a press release.

The seven party alliance prior to the mass revolution appealed the trade Unions, professional workers, teachers, students, industrialists, traders, Government employees, farmers and the common mass to come to the street against the Government on one side and on the other hand, the government was preparing a strategy to suppress the general uprising. The government tried to discourage the mass psychologically stating the participation of Maoists terrorism in the movement. The state-owned newspaper 'Gorkhapatra' published the press release of Home ministry as stated; 'HMG requests all the people to stay aloof from the activities in which there is possibility of involvement of terrorists or organized by them because the security forces would be taking necessary actions to control the terrorist acts (Gorkhapatra, April, 5, 2006). The then Gyanendra's government enforced prohibitory orders effective from 6th April. On 5 April, the Government had arrested the top party leaders of the political party, Journalist, professors, students etc. 
In the initial stage, a four days strike failed to achieve its set objective and the strike continued for 19 days. On the first day of the general strike in the country, the economy and the government administration became functionless. The mass movement received unity and support from journalists, lawyer, business professionals, medical professionals, professors, engineers etc (Kantipur, April 7, 2006). On 6 April, the medical professionals of T.U. Teaching Hospital showed their allegiance and support to the mass movement and demonstrated one-hour protest in the hospital (Kantipur, April 8, 2006). The Government with a motive to suppress the movement cut off the mobile services and imposed curfew at daytime in Kathmandu valley but the people showed their civil disobedience and kept on protest against the government. The mass demonstration spread nationwide and it remolded into the death of a demonstrator at Pokhara in the police firing.

The four-day strike could not achieve the goal and the seven party alliances decision to continue the protest for indefinite period until and unless they attain success received full support from the people. The continued mass demonstration had slackened the country and even tourist joined the mass movement on the 11th days of the protest. On 16th April, the seven party alliance appealed the people to come to the street against the Government. Asking the Nepalese people working in foreign countries not to send remittance to Nepal, to boycott the production of the industries and factories run under the ownership of king and the royal family, to refrain going to the government office, not to pay taxes, custom duties, VAT, electricity bills, water bills, and so on. The Government on the other hand did its best to suppress the movement. It imposed curfew, held lathicharge at peaceful demonstrators, tear gas, as well as firing at the mob. Even then, the rapidity of the revolution did not lessen but gained 
impetus and momentum. The new year (according to Nepali calendar) started in Nepal on April 14 and there is a tradition of the addressing the nation on the New Year day by the king. The people expected the demand from the king but it failed to solve the problem and instead the king insisted for dialogue and to hold the election. The king's address to the nation shattered the hopes and aspiration of the people. The king started consulting the leaders. On 17 April, king gave audience to ex. P.M. Krishna Pd. Bhattarai and Surya Bd. Thapa and on 18 April, Lokendra Bd. Chand, Marichman Sing Shrestha, Nepal Sadbhabana Party chairman Badri Pd. Mandal and National Democratic Party chairman Pashupathi Samser JBR. The mass revolution day by day gained momentum and the people became more and more aggressive against the monarchial system. On 21 April, the king address the nation asking agitating party to submit the name of the candidate for Prime Minister, which was a traditional tactics of king Gyanendra and further blamed the political parties for not supporting him to maintain law and order, to check corruption and to hold the general election after he had taken the executive power of the country (Nepal Television, April 21, 2006). This message further infuriated the protestors who were against the traditional monarchial system. The demonstrators signaled the Royal address as a setback and the seven party alliances ignored the king's declaration and decided to continue the mass movement and there was wholehearted support and sympathy to the movement from many countries and the Nepalese people. The seven party declared to stage 2 million demonstrators in Kathmandu valley on the night of 24th April, the king addressed the nation stating the revival of the house of representatives which was dissolved on May22, 2002 (Nepal Television, April 24, 2006). This proclamation opened the door to settle the disputes 
because this was the main demand of political parties and the mass revolution II ended.

The description of the loss of human power during the revolution -Death -21, Injured-3723, Arrested- 2979, Unknown were abouts-18, (Source: Jana Andolan II, pp.230329)

\section{Role and interest of International community}

Throughout the revolutionary period, many foreign countries and international organization played a vital role in solving the Nepalese issue for the re-establishment of Democracy in Nepal. On the 14April, Secretary General of UNO Cofi Annan in a press release stated that the king should take far-reaching step to check further bloodshed and to calm the deteriorating situation (Kantipur, April 15, 2006). The international Forum for Journalist (IFJ) appealed the UNO to pressurize the king to grant democracy to the people (Kantipur, April 15, 2006). During the course of the revolution, the special envoy of the Indian p.m., parliamentarian Karan Sing, arrived Nepal on 19th April to suggest the king for solving the current affairs of the state (Kantipur, April 20, 2006). In a similar manner, the European mission led by the Honorable Ambassador of Finland to Nepal met the leader of the seven agitating parties to come to dialogue after the king's proclamation on 21 April. India too stated the king proclamation as positive step. But the rejection of the king's address by the agitating parties, the Indian secretary of foreign affairs changed its attitudes by stating "Nepal's future is to be determined by the Nepalese itself (International Forum, May\April, 2006). The king's address to the nation of 21 April was welcomed by America, Britain, and Finland too. 
Various international Human Rights Organizations, UNO, some members of American congress condemned the Nepal's Government for suppressing the mass agitation and violating the international laws. The office of the United Nation Office of the High Commissioner for Human Rights in Nepal in a press release of April 8 and 11 stated to stop the repressive force against the demonstrator. Then after, the statement given on behalf of UN Secretary General the spokesman said that the king and political parties most work united to solve the current political turmoil. In a similar fashion, the general convention on Human Rights Watch, international commission of Jurists demanded restriction to king Gyanendra, his high level official, and top level security personnel for their entry to any other country. On April 20 the president of international federation of Journalists Christopher Warren stated, "we are imploring the government to show respect for human rights and not allow the peaceful demonstrations to turn into bloodbath. Similarly, the Asian Forum for Human Rights and Development protested for the suppression of revolutionary faction by the security personnel and expressed that the king Gyanendra had already lost the trust and confidence of the people.

The international community desired the king and seven agitating parties to come to dialogue to check the outburst of the revolutionary movement further more. Amongst the int'l organizations, especially the Human Rights activities protested for the gross violation of human rights during the revolutionary Period from the security personnel.

\section{Causes of Revolution}

King Gyanendra had dismissed the people's elected government on Oct.4, 2002 and captured the power of the rule of the country. The House of Representative had been 
dissolved and the new election was in due. Then after the king began to nominate his own trusted person to prime minister and formed the cabinet on his own accord. He could form and dismissed the cabinet as his sweet will. From the period of 4 Oct.2002 to Feb.1, 2005, the king appointed three prime minister and dismissed them. Every time, he addressed the nation that he looks for an honest, clean person to hold the post of p.m. but did not appoint any suitable candidate to fulfill his above criteria. The political parties too had hope and expectations to form the Government but the king reluctantly ignored. As a consequence, the political parties were left with nothing except to stage a revolutionary movement. On Feb.1, 2005 the king formed the council of minister under his chairmanship which led to the establishment of absolute monarchial system. This move of the king was unacceptable to the people as the people had already put an end to absolute monarchial system by the mass revolution of 1990 .

During the direct rule of the king, all sorts of democratic system were paralyzed. The dissolution of the House of Representatives and the failure to hold fresh election on one side and on the other hand the local level government was no more as the terms of the local body has expired. In such a critical time, the king without the consent and participants of the major political parties dramatically held the election of town municipalities. The country was administered through the ordinances of the king. After the Feb.1 2005 incident, the king's government imposed the state of emergency thereby hampering most of the fundamental rights of citizens as it had been suspended to a great extent. Although the king had time and again showed his commitment to multiparty democracy and constitutional monarchy in his address to the nation, he had weakened the administrative machinery; people were deprived of rights to information and important public matters. So, the dissatisfied political parties 
had no other options left them to mingle in revolutionary movement.

The situation of human rights during the direct rule of the king was deplorable. The Amnesty International on May 24, 2005 reports the Human Rights situation in Nepal is in the worst state in the world. Likewise UN Human Rights organization representative Ian Martin highlighted the human rights situation in Nepal as the Government carried out arrests to the leaders and Parties workers, the arrested ones were kept in a deplorable condition, the right to freedom movement was banned to the leaders (International Forum, May\April, 2006).

Another cause of the mass revolution was to put an end to the 10 years long civil wars led by the CPN (Maoist) and establish lasting peace in the country. The people's war led by Maoists had cost the lives of thousands from both government side as well as Maoist side. Abduction, injured, disabilities and hundred thousand people became homeless, orphans etc. This situation was not congenial atmosphere for industrial and civil society. So, there was needed to put an end permanently to wars, violence, corruption, political instability, violation etc. It was pleasant opportunity to king Gyanendra if he had worked earnestly to avoid the social evils like corruption, violence and political instability, he would have got support and confidence from the people of the grass root level. But he failed to do so and people had came forefront themselves.

\section{Success of the revolution}

The Nepalese people wanted to get free from various problems like suppression, violence, corruption, political instability. But the parliamentary Parties representing the people had lost the faith and confidence of the people. The CPN Maoists had too failed to get the trust of the people at 
this critical situation. A historical events down on Nov.22, 2005 when the seven agitating party and the CPN (Maoists) signed a twelve-point understanding which implanted hope and aspiration to the people. This agreement was the foundation stone for the success of the mass Revolution II. Besides these, the commitment of the seven party alliance, undeclared participation of Maoist in the movement; whole hearted support and participation of various professionals, Industrialists; moral support of international community and the common mass in particular, paved the way of its success.

\section{Result of the Revolution}

It led to restoration of the dissolved House of Representatives, formation of all party Government, ensure sovereignty inherent in the people, to hold peace talks with the CPN (Maoists), to bring permanent peace and tranquility in the country, to hold the election of the constituent assembly. Similarly, the parliament was able to cut off all the authority and privileges of the king. Finally, constituent assembly declared the end of monarchy and establishment of republican state to Nepal on May 28, 2008. With the end of monarchical system, many cultural practices associated with them have either finished or changed. Mass people of Nepal always believe the king as an incarnation of Vishnu, the Hindu God. People used to take tika on their forehead by the king in Vijaya Dasami, a Hindu festival. In the very occasion, tika (rice-grain mixed with red color) and jamara (seed of different grain germinated within the house in the vijaya dassmi) had been brought from previous royal palace of Gorkha to Narayanhiti palace of Kathmandu. King visited the Kumari Ghar once a year to take a blessing from Kumari, the living Goddess of Nepal. King used to took a part as an observer in the popular Newari festival like bhoto jatra, rath jatra etc. 
With the end of Kingship, the culture of coronation ceremony has become the history.

\section{Conclusion}

The 19th day's revolution was against the royal takeover which became the immediate causes of the mass revolution but in reality, the movement was the explosion of the problems the Nepalese people had effaced for years like exploitation, mal- practices, corruption, and lack a peace and security. This movement succeeded due to the support of Maoists, seven party alliances, the common people in general, various professional workers and the support and wishes of the international communities.

This movement was launched in a peaceful and of non violence nature but the government used force, subjugation, oppression, and firing leading to loss of human power. The protestors protested in a peaceful manner, making neither any physical damage nor loss of human power. Therefore, this movement aimed non violence which was the most effective tool to achieve success and the people proved themselves as unvanquished power. The full 19th day's movement was accompanied by general strike; it was a decentralized movement from the capital to cities and finally to the rural areas where people of different walk of life participated to make it a grand success. This revolution ends the political and cultural institution of monarchy from the only one Hindu kingdom of the world.

\section{References}

Aryal, K. \& Poudel, UK (ed.) (2006). Jana-Andolan II: A Witness Account, Kathmandu

Gorkhapatra(national daily Nepali Newspaper)

Kantipur (national daily Nepali newspaper) 
RESEARCHER I II JULY-DECEMBER 2013

Nepal Television_(State-owned television channel of Nepal) International Forum (A monthly magazine in Nepali vernacular) 